\title{
A NEW SPECIES AND VARIETY OF SCLEROCACTUS FROM ARIZONA ${ }^{1}$
}

\section{Elzada U. Clover}

Sclerocactus havasupaiensis sp. nov. Simplex cylindricus erectus vel curvatus, $1.5-4.2 \mathrm{dm}$. altus, 8-11. cm. crassus; areolis subrotundis ; costis 13-18, tuberculis prominentibus, spinis lateralibus 6-13, ra-

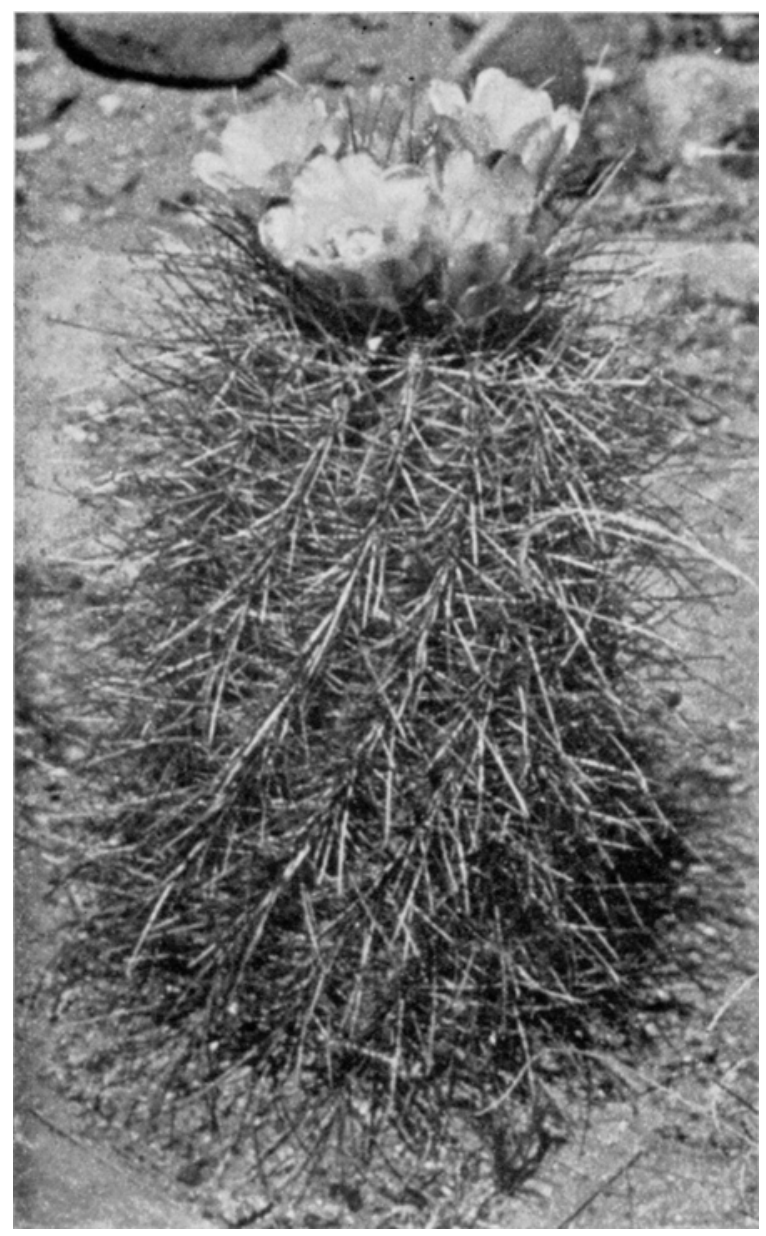

Fig. 1. Sclevocactus havasupaiensis Clover, sp. nov. Actual type specimen photographed in natural habitat at Havasupai Canyon, Arizona (Clover 5229 in part: there are several cotypes).

diatis, flexuosis, albidis, apice adustis, $10-20 \mathrm{~mm}$. longis ; centralibus 4-9, flexuosis, angulatis, curvatis, summis 3 compressis, pellucidis, ascendentibus, curvatis, $1-41 / 2 \mathrm{~cm}$. longis; inferioribus angulatis, purpureo-fuscis, $6-7 \mathrm{~cm}$. longis ; floribus in axillis summis, numerosis (vel usque ad 30 ), $3-51 / 2 \mathrm{~cm}$. longis, $3 \mathrm{~cm}$. crassis, 5 -seriatis ; segmentis $23 / 4-3 \mathrm{~cm}$. longis, apice obtusis, brevi-apiculatis, crassis, exterioribus in media parte atro-purpureis, margine albis; interioribus albis sed deorsum viridiusculi-luteolis visis; stylo viridi-luteo, $2 \mathrm{~mm}$. crasso, glabro, stigmatis

1 Received for publication November 17, 1941.

Papers from the Department of Botany and the Botanical Gardens, University of Michigan, no. 793 . lobis viridi-luteis, 6-8, deliquescentibus; filamentis numerosis, delicatis, viridi-luteis, antheris lutei-aurantiacis, stylo brevioribus; fructibus carneis, purpureis, sed postea siccantibus. Specimen typicum siccatum ex loco dicto "Havasupai Canyon," Arizona, conservatum est in Herbario Universitatis Michiganensis (Clover 6404). Specimen vivum est in Horto Botanico Universitatis Michiganensis, Ann Arbor, Michigan.

Plant solitary, reaching a height of $42 \mathrm{~cm}$, diameter $8-11 \mathrm{~cm}$; ; ribs $13-18$ often spiraled, prominent, usually $1 \mathrm{~cm}$. high, more or less tubercled; areoles subcircular, 7-12 $\mathrm{mm}$. apart and alternating with those of adjacent ribs; glands in groove above young areoles well developed, 1-3 or sometimes as many as 6 , yellowish to red, exuding considerable sweet, clear nectar; young seedlings $1 \mathrm{~cm}$. in diameter bearing both radial and well-developed central spines; radial spines on mature plants $6-13$, usually about 10, white with dark tips, flexuous, terete to flattened, acicular, $10-20 \mathrm{~mm}$. long, lateral radials usually longer than upper and lower ones; central spines various, 4-9, often with upper ones ascending, straight, flattened and translucent, $4-41 / 2 \mathrm{~cm}$. long, sometimes resembling radials, lower centrals curved or hooked, flexuous, angled, extending variously, the longest $6-7 \mathrm{~cm}$., always hooked and usually pointing downward, reddish, variegated red and white to

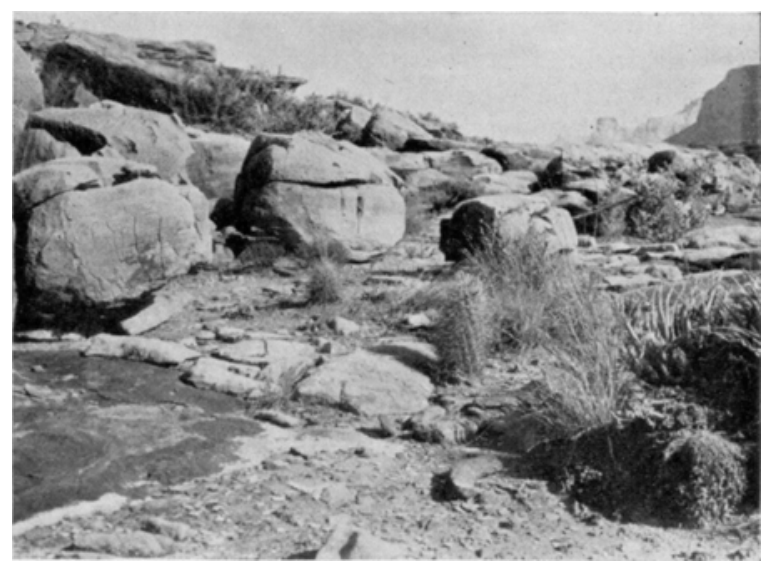

Fig. 2. Sclevocactus havasupaiensis Clover sp. nov. Two specimens in natural habitat on top of Supai sandstone formation showing association with Ayave utahensis, Rhus trilobata, Coleogyne ramosissima, Ephedra and certain grasses.

almost black; flowers campanulate, appearing near the apex in upper part of the areole, as many as 30 buds and flowers at one time; flowers $3-51 / 2 \mathrm{~cm}$. long, $3 \mathrm{~cm}$. across; perianth segments in 5 whorls, the two outer with segments short and obtuse, margins whitish with purple-drab shading to greenish up trace, inner segments entire, yellowish-green at base fading to almost white toward tip, $2-3 \mathrm{~cm}$. long, $11 / 2 \mathrm{~cm}$. 
broad below the middle; scales on the ovary few, conic with rounded base, scarious, brown up trace, deciduous, $2 \mathrm{~mm}$. long and containing sparse wool in axil; filaments extremely delicate, pale green, anthers bright orange, stamens shorter than the style, style $2 \mathrm{~mm}$. in diameter, pale yellowish-green, stigma lobes $6-8$, about the same color as style, glabrous, deliquescent, lobes appearing paired when immature, $31 / 2 \mathrm{~mm}$. long, blunt-tipped; flowers remaining open several days, faintly scented; fruit about $1 \mathrm{~cm}$. long, oblong, turning purplish but drying later; seeds shiny black, tuberculate, $21 / 2^{-3} \mathrm{~mm}$. long, much larger at upper end, hilum lateral, large, subcircular, much depressed. The type specimen (fig. 1) was collected by William Belknap, Jr., April 26, 1941, on top of the Supai Formation in Havasupai Canyon, Arizona, where the species grows abundantly. Specimens not in flower were previously collected by the author in $\mathrm{July}, 1940$, in Havasupai Canyon (Clover 5229) near Navajo Falls, and in Hualapai Canyon (Clover 5100) on talus of the Supai Formation. A few plants were seen on the floor of Cataract Canyon above Supai, September, 1941.

This cactus more closely resembles $S$. parviflorus Clover than other species, but differs from it in several respects. The general appearance is less shaggy, and the central spines are more delicate and less flattened. Of the radial spines the lower ones are the longest in $S$. parviflorus. This new species usually has the lateral radial spines longer than the lower ones. Inner perianth segments of the Colorado River species are phlox purple; style and stigma lobes are also purple. The Supai species has whitish inner segments shading to yellowish-green below. Style and stigma lobes are pale yellow-green.

Sclerocactus havasu paIensis Clover var, roseus var. nor. Floribus roseis, suaveolentibus; segmentis perianthii oblongis, acuminatis; stylo viridi-luteo, $1 \mathrm{~mm}$. crasso, glabro, stigmatis lobis purpureo-rubris, acuminatis. Specimen typicum legit E. Clover $\& \mathrm{Wm}$. Belknap, Jr. (Clover 6403), in Havasupai Canyon, Arizona, siccatum est in Herbario, Universitatis Michiganensis.

Similar in habit to typical S. havasupaiensis; flowers pale rose-pink with inner segments shading to pale yellow-green at base, decidedly sweet-fragrant; inner segments oblong, tips acuminate; style pale yellowish-green, stigma lobes reddish-purple, tapering toward the tip, not appearing paired when immature, not deliquescent; seeds with prominent tubercles. This variety was found in association with $S$. havasupaiensis on top of the Supai Formation in
Havasupai Canyon, Arizona, April 26, 1941. Young seedlings were growing at the base of the plants. Additional plants were collected by C. F. Shaffer, Jr.,
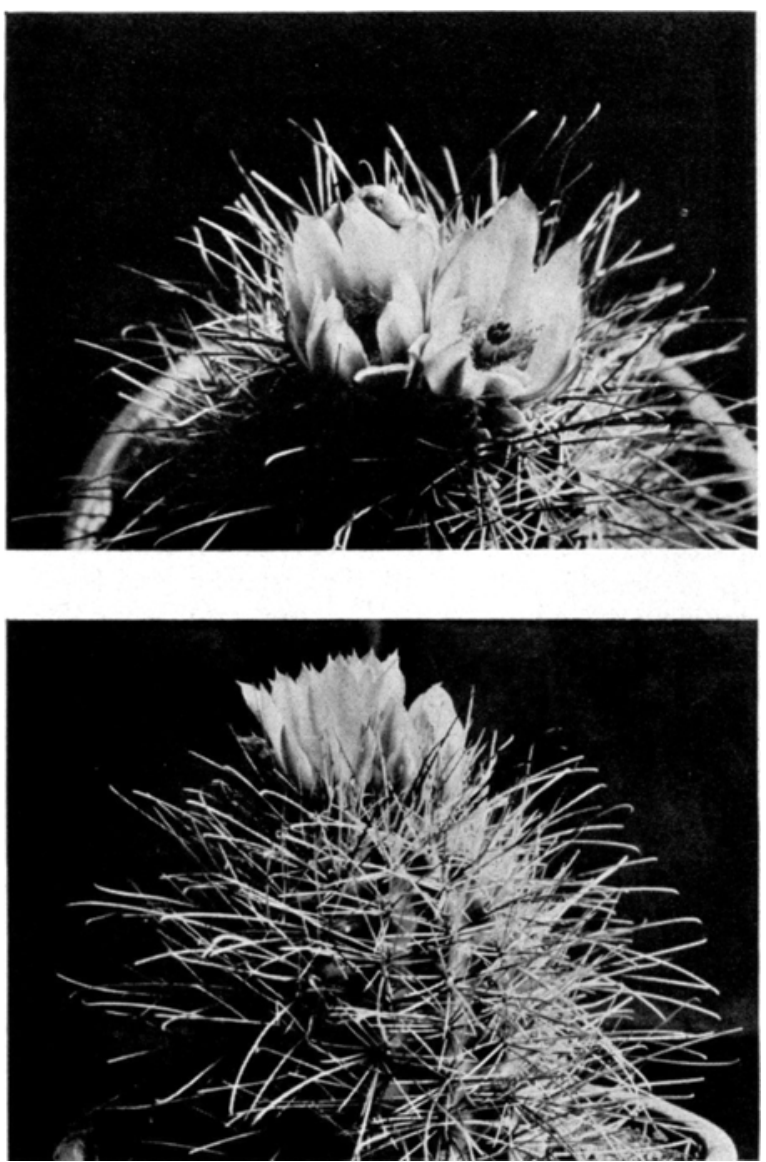

Fig. 3-4. Sclerocactus havasupaiensis var. roseus var. nov. Actual type specimen (Clover 6403) photographed while alive at Botanical Garden, University of Michigan, now dried and preserved as a herbarium specimen. Additional plants of the same collection (cotypes) are in the living collection (Bot. Gard. no. 18079).

in the same location in May, 1941, and are in the living collection (no. 18079) in the Botanical Gardens, University of Michigan.

Botany Departarent,

University of Michigay, Axs Arbor, Michigan 